\title{
The Relationship Of Regulatory Of Leadership Changes Toward Employee Motivation At Polytechnic LP3I Bandung
}

\author{
Yuyun Taufik, Iin Kurniawati \\ Politeknik LP3I Bandung, J1. Pahlawan No.59 Bandung 40123, Indonesia \\ Politeknik LP3I Bandung, Jl. Pahlawan No.59 Bandung 40123, Indonesia \\ yoenta_72@yahoo.com, iin.kw.saja@gmail.com
}

\begin{abstract}
The main objective of this study is to determine the relationship of regulatory changes in leadership and employee motivation at Polytechnic LP3I Bandung.

Using a qualitative descriptive research method correlation. Sampled population / resource was permanent employees of LP3I Polytechnic Bandung who have worked for 10 years using simple random probability sampling technique natural setting research instrument through interviews, observation, questionnaire and joint / triangulation. Analysis of data is a cultural theme (discovering cultural theme) find a relationship between the domain and the relationship of Hypothesis associative research: whether there is a significant relationship between the regulatory of leadership changes and employee motivation at Polytechnic LP3I Bandung.

The results of this study ; the author found a significant association between the regulation of motivation that includes motivational factors (performance, responsibility, work itself and recognition) and hygiene factors (wages, job security, working conditions, status, procedures, quality supervision and quality of interpersonal relationships ).

As a growing organization at Polytechnic LP3I Bandung that rapidly changes in dynamics, it requires proper handling in order to achieve organizational goals.
\end{abstract}

Keywords:

Leadership, motivation, employee

\section{PART I}

INTRODUCTION

1.1 Background

The leadership plays a very important role in all areas. Without the leader, the goals of the organization that created it would be meaningless because there is no person who acts as a unifying the various interests that exist. Leadership is no longer seen as a signpost, but as partners together with other members in their efforts to achieve common goals.

Leader is someone who uses his ability to motivate, guide, encourage subordinates to do something that the intended joint and can influence others to do the activity together for the sake of an achievement. The leader is also a role model for his subordinates or reflection. Leadership is an attitude of a leader to perform a process that affects the activities of the group are set to achieve a common goal.

The success of an organization in achieving its objectives depends on the leader, whether the leadership is able to mobilize all human resources, facilities, funding, and time effectively and efficiently in a management system is to make employees as partners rather than as subordinates. Along with the development of the science and technology as well as the demands of globalization, it also required the presence of resources that employees can work efficiently and effectively, and have the knowledge and skills that can show satisfactory performance. To build a quality human resources is required systematic effort that one of them is a leadership style that is applied.

The increased importance of Human Resources for the company engaged in the provision of education, including private universities. Without the support and human resources that are reliable, then the process of learning and service to students and faculty become obstructed. It is clear that the organization in carrying out its activities is required to be able to run quickly, smoothly and focused in 
order to improve services to students and faculty as well as in achieving its objectives effectively and efficiently.

Polytechnic LP3I Bandung is one institution that was founded in Bandung in 1998 that was once not D3 but the Business College. In 2001, due to demand and request then turned into a Polytechnic graduates. For approximately 17 years of existence, there are 8 times the turn of the director and the Polytechnic LP3I Bandung. Surely turn of the leadership here brought significant changes both of the organizational structure, policies, rules and also the achievement of the organization itself. Polytechnic LP3I Bandung itself is one of the Polytechnic under LP3I foundation based in Jakarta. LP3I Foundation itself engaged in education services, in addition Polytechnic Polytechnic LP3I namely Bandung, Jakarta and Medan, foundations LP3I also establish educational institutions for students of S1 and S2 (for instances: STIAMI Jakarta, STIA Banten and so on ). As for the educational institutions in the form of a business college there are around 40 branches throughout the province of Indonesia.

During the 17 years of the establishment of educational institutions formerly Polytechnic LP3I Bandung shaped business college, of course, a lot of the dynamics of positive and negative changes that have occurred. The dynamics of change was a normal happening anywhere instituted, but certainly changes that occur due to changes in policy because of the changes of the leadership should be addressed wisely by LP3I foundation that become decisionmakers.

\subsection{Focus Research}

Due to the limitations of the study of the whole object of the research is focused on organizational factors and employee motivation / subordinate only.

\subsection{Problem Formulation}

1. How is employee motivation when regulatory changes in the leadership of the Polytechnic LP3I Bandung?
2. What is the relationship between the regulatory changes in leadership and employee motivation at the Polytechnic LP3I Bandung?

\subsection{Research Objectives}

To determine the image:

1. Motivation of employees when regulatory changes in the leadership of the Polytechnic LP3I Bandung.

2. The relationship between the regulation changes of leadership and employee motivation at the Polytechnic LP3I Bandung.

\subsection{Study of Theory}

\subsubsection{Leadership}

\section{A. Human Resource Management}

Management of human resources according to T. Hani Handoko (2003: 6):

"It is a process of planning, organizing, directing, and monitoring the activities of procurement, development, compensation, integration, maintenance, and release of human resources in order to achieve various goals of individuals, organizations and society.

B. Theory of Leadership

The definition of leadership proposed by experts according to Fahmi Irham $(2013 ; 16)$ :

a. Stephen P. Robbins: leadership is the ability to influence a group toward the achievement.

b. Richard L. Daft: Leadership is the ability to influence others that leads to the achievement of objectives

c. GR Terry: Leadership is the activity of the Influencing people to strive willingly for mutual objective.

d. Rick W. Griffin: individuals who are able to influence the behavior of others without having to rely on violence; leader is an individual who is accepted by others as a leader. 


\section{Management Leadership}

Leadership Management is a comprehensive science that examines how people carry out leadership by using all resources owned by always put forward the concept and the rules that apply in management science.

According Irhami Fahmi $(2013 ; 2)$ Good leaders are:

"Being able to understand a problem before the problem arises, and a leader who understands the wise is in the on capacity and competencies possessed by a subordinate as a whole".

The concept of The Right Man and The Right Place in Management Science Leadership is a concept or way of leadership positions placing an employee in the form of promotion is not in accordance with the educational background owned, autonomous decision is the authority of a leader, but in the context of management science is not proper.

Actually, this concept is not spotted and seen how to place an employee in accordance with a ability, but also to be seen opposite of how a leader to put their knowledge of ownership in accordance with the decision of ownership does. For example, the manager is considered to have a high capacity capabilities in the technical field, this occurs because these managers have a strong relationship with any decisions that are technical, such as programming, data processing, preparation of files, and various other basic rules in the field of high administration. Higher become manager someone the less use of technical knowledge, and furthermore he is increasingly moving to the use of the science of human relationships

Irhami Fahmi $(2013 ; 31)$ says that being a leader is not obtained by accident, but no background or things that make someone a leader, namely:

a. Tradition / heritage, one becomes the leader because tradition / heritage, such as kings or queens of England. b. Good personal strength for physical reasons or because of his skill.

c. Appointment boss, a good leader because of the promotion by the superiors

d. Election, one becomes a leader because the concept of acceptance / acceptance theory you become a leader and we obey your instructions.

\subsubsection{Motivation}

Koontz (1990: 115) states that:

"The motivation of people depend on the strength of the existing motif. Motive means a situation in oneself (inner state) that encourage, enable, mobilize, direct and channel behavior towards the goal. "

Manulang (1982: 76) states that:

"Motivation means something stimulation or stimulation condition. So motivation can also be interpreted factors that encourage people to act in a certain way. "

A leader can involve people who lead by creating the conditions that drives motivation of employees as follows: motivation can be developed to find the need (subordinate) physical, safety, mental, psychological, social, and economic in the work environment and create the conditions for compliance those needs. Needs can be a motivational factor that could encourage subordinates to work, and motivation can be developed by creating a desire to work hard / hard, achievement and success . The willing for hard work, achievement, and success can be encouraged by providing suggestive challenge that gives motivation to act out.

A wise leader can develop the motivation of the employees with the basics of motivation is a force of change in a person who is characterized by affective encouragement and reactions to achieve the goal. Motivation is part of learning. Of understanding the motivations appear to be three things: motivation starts with a change of power in a person, the motivation was characterized by affective impulse that sometimes appears and sometimes difficult to 
observe, the motivation is characterized by reactions to achieve the goal.

Motivation in leadership is intended to provide a boost for every employee to engage in work optimally. This can be done by building, encourage, and support the spirit and morale with a positive force (to avoid manipulation). Leaders need to give them incentives to those they lead learn to appreciate the work and grateful for any work that achieved . They should be aware, that excel in the work actually raise self-esteem them .They also be encouraged to work actively carried out with joy, so that bring positive benefits and value to themselves, leaders, organizations, and work environment.

Maslow's theory of motivation developer, known as the hierarchy of Needs Theory (Need Hierarchy Theory) explains that human needs are arranged from the most basic needs to the needs of the most high, according to Maslow as quoted by Mangkunagara, (2009: 95) that in humans there are 5 requirements are:

1. Physiological needs: the need to eat, drink, physical protection, breathing, sexual. This requirement is a requirement lowest level or also referred to as the most basic needs.

2. The need for a sense of security that needs to be protected from the threat, danger, conflict and the environment.

3. The need to feel they have that need to be accepted by the group, affiliated, interact, and the need to love and be loved.

4. The need for self-esteem that needs to be respected, and appreciated by others.

5. The need for self-actualization is the need to use the abilities, skills and potential to express ideas provide an assessment and critique of something. 
Need Hierarchy from Maslow will be presented as a pyramid follow:

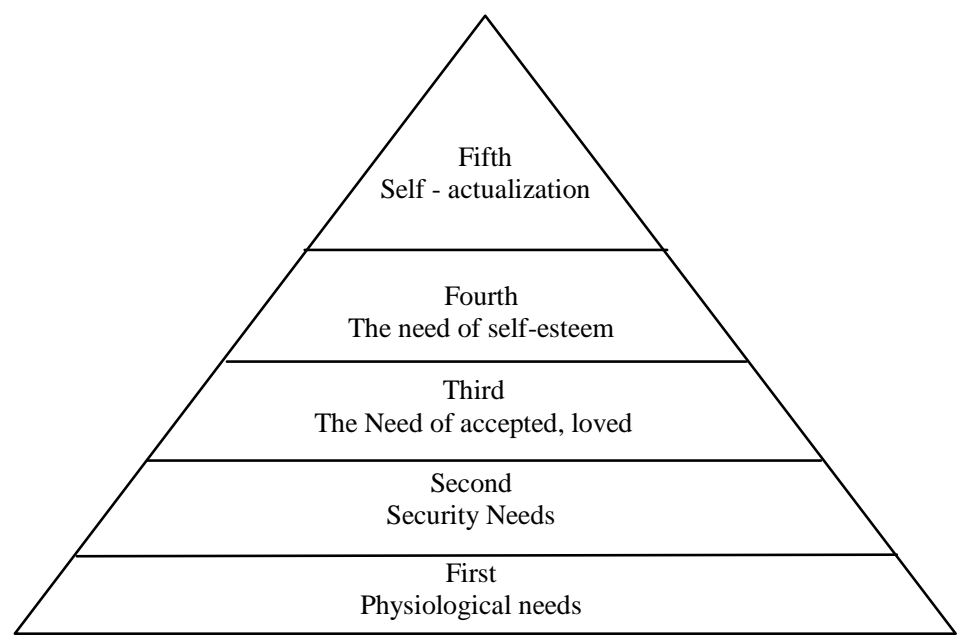

Picture 1.1 The Theory of Need Hierarchy

Tabel 1.1 The Theory of Need Hierarchy

\begin{tabular}{|l|l|l|}
\hline Need Hierarchy Theory & General Factors & Organization Factors \\
\hline Physiological Needs & Food, drink, housing, sex & salary, working atmosphere, facility \\
\hline Security Needs & Security, Protection, Stability & Safety work, social security, pension. \\
\hline Social Needs & Friendship, care, sense of belonging & Supervision, team work \\
\hline Self-Esteem Needs & acknowledgement, status, & Bonus, title, responsibility, reward \\
\hline Self - actualization Needs & $\begin{array}{l}\text { Development, Achievement, } \\
\text { Progress. }\end{array}$ & achievement, challenge, Progress in organization. \\
\hline
\end{tabular}

Higher requirement factors shown in Table 1.1. Need Hierarchy Theory is comprised of Maslow's theory of selfactualization and awards. Every employee especially the staff who occupies higher levels of management within the organization will be compelled to perform a high work by implementing an adaptive organizational culture, consisting of (1) oriented work; (2) competition; (3) a greater emphasis on professionalism in making decisions; (4) develop a means of working with the system of work teams; (5) pursue career opportunities that exist; (6) take 
advantage of the policy system of leadership within the organization and (7) compensation dynamics within the organization

\section{CHAPTER II}

\section{RESEARCH METHODS}

Research

Methods

Qualitative research methods to determine regulatory changes in leadership and employee motivation at Polytechnic LP3I Bandung because the issues to be discussed are complex and dynamic, focused on the assumption restriction issues and employee motivation / subordinate only.

Formulation of the problem is descriptive or where researcher explored and photographed the social situation to be studied thoroughly, broad and deep understanding of employee opinions about regulatory changes in leadership, employee motivation when regulatory changes in leadership as well as the relationship between the regulatory changes in leadership and employee motivation at Polytechnic LP3I Bandung

Population / social situation include: place; Polytechnic LP3I Bandung, the perpetrator is employees of Polytechnic LP3I Bandung and They are as permanent employees.

Samples theoretical / resource persons are employees who have worked more than 10 years. Sampling techniques using simple random probability sampling technique natural setting through interviews, observation, questionnaire and joint / triangulation. Inductive data analysis is an analysis based on data obtained subsequently developed into a hypothesis. Then searched again repeatedly in triagulasi then the hypothesis is accepted and developed into a theory. Data analysis of cultural themes (discovering cultural theme) find a relationship between the domain and how the relationship of leadership and regulatory changes in employee motivation at Polytechnic LP3I Bandung. The hypothesis of the study that author propose is associative hypothesis whether there is a significant relationship between the regulatory changes in leadership and employee motivation at Polytechnic LP3I Bandung.

Ho: $\rho=0,0$ means there is no correlation Ha: $\rho \neq 0$, "not equal to zero" means a greater or less (-) from zero, it means there is a relationship $\rho=$ value of correlation in the formulation hypothesized.

\subsection{Research Findings}

1. General description of the object to be examined 2. Physiological needs which include: salary, pleasant working conditions and working facilities 3. The need for a sense of security that include: safe working conditions, social security, pension and job security.

4. Social needs which include: the quality of supervision, work group / team.

5. Needs awards include: bonuses, job title, responsibilities and

rewards

6. The need for self-actualization which include: achievement in the work, challenging tasks and progress within the organization; 


\subsection{Discussion}

1. Motivation of employees when regulatory changes in the leadership of the Polytechnic LP3I Bandung. Motivation is an impulse arising from within oneself, whether conscious or not to perform an action with an action with a specific purpose. So an employee can be motivated to do the job thoroughly, discipline and loyalty will affect the work / performance of employees. Motivation is influenced by physical needs, abilities, social, ego and self-development, motivation factor is closely linked to the performance of an employee because the urge someone to do a job / task in order to achieve the goals that will appear excitement of working for doing a good job.
Polytechnic LP3I Bandung's employee motivation will look at the physical ability, experience and education when employees have the ability to perform tasks in the waistband, then the task will be able to be resolved properly and vice versa employee's ability to perform his duties, the lack of organizational development will decline. The tendency of decreasing productivity of employees in the achievement of regulatory agencies at the time of the change of leadership at Polytechnic LP3I Bandung. Below are shown a glimpse of one of the target amount of data on the development of new student recruitment LP3I Bandung Polytechnic from 2012 till 2014.

\section{Tabel 1.2}

The Target freshmen students recruitment of Polytechnic LP3I Bandung, from 2011-2014

\begin{tabular}{|l|l|l|l|l|}
\hline Description & \multicolumn{4}{|l|}{ Years } \\
\cline { 2 - 5 } & 2011 & 2012 & 2013 & 2014 \\
\hline Target & 1016 & 1016 & 1198 & 1500 \\
\hline Candidates & 1187 & 966 & 961 & 615 \\
\hline Enroll & 1025 & 811 & 743 & 589 \\
\hline Registration & 971 & 777 & 726 & 575 \\
\hline
\end{tabular}

Source : Marketing Division of Polytechnic LP3I Bandung 2014

From the table above indicate that, a decrease in employee productivity can be seen from the failure to achieve targets such as recruitment agencies freshmen from 2011 to 2014. The decline in the achievement of new student recruitment at the Polytechnic LP3I Bandung, this one was the change of leadership of previous director, Ir. Adriza, M.Si which led from the period 2005 to 2013 , to the new director Mr. Kamalludin Yusuf, SE which led from 2013 to 2015. From the data above showed that the growth in the number of new students on average every year are not able to achieve the specified targets, a trend to decrease every year further away from the target average is increasing every year. This trend will certainly have a major impact for the development and growth of the institution, but it also can interfere with the achievement of organizational goals, therefore, review the style of leadership with the policy changes that were made to steer the employees towards the company's goal to be achieved should be observed with more depth with the aim to improve Polytechnic LP3I Bandung especially and generally for the foundation of LP3I in the future.

2. The relationship between the regulation change of leadership and employee motivation at the Polytechnic LP3I Bandung.

There are some factors that make someone become a leader, namely: 
1. The tradition

2. The good personal strength

3. Appointed by boss, promoted by the superiors

4. Election

Due to the policy of LP3I foundation, that all of directors must be decided by headquarter in Jakarta. (Centralized LP3I Foundation), so the changes of top management especially the director position is in the hand of LP3I foundation in Jakarta. Sometimes the foundation can not find the right person to be the leader because of the family policy in the foundation. It should be the other factors come to the first priority in decision becoming a leader for example: the capacity and skill of the candidate.

\section{CHAPTER III}

\section{CONCLUSION}

In studies that have been conducted author found that the close relationship between the regulation and motivation that includes motivational factors (performance, responsibility, work itself and recognition) and hygiene factors (wages, job security, working conditions, status, procedures, quality supervision and the quality of interpersonal relationships

\section{References}

Anwar Prabu Mangkunegara.(2009). Manajemen Sumber Daya Manusia.PT. Remaja Rosdakarya. Bandung. Arikunto.(2006).Prosedur Penelitian Suatu Pendekatan Praktik, Ed Revisi VI.PT Rineka Cipta. Jakarta.

Bernardin, John H., \&Russel, Joyce E. A. (1993).Human
Burhan.Singapura.

. Irham Fahmi,S.E., M.Si, Manajemen Kepemimpinan,

Alfabeta, CV Bandung, 2013

Sugiyono.(2009).Metode Penelitian Kuantitatif dan Kualitatif. CV.Alfabeta. Bandung.

T. Hani Handoko. (2003). Manajemen.BPFE. Yogyakarta.

Veithzal Rivai. (2010). Manajemen Sumber Daya Manusia Untuk Perusahaan. Rajawali Pers. Jakarta. 